\title{
Wetenskaplikheid en konfessionaliteit van die teologie: Enkele gesigspunte in verband met die teologiebegrip van J A Heyns
}

C J Wethmar

\section{ABSTRACT}

The scientific and religious nature of theology: a few issues raised by the concept of theology in the work of $\mathbf{J}$ A Heyns

This article investigates the notion of theology in the work of $J$ A Heyns. The embeddedness of Heyns' usage of this concept in the tradition of Reformed thought and in particular in $H G$ Stoker's philosophy of science is traced. The advantage of this influence on the theology of Heyns is discussed and a few as yet unresolved issues are indicated.

Wie 'n skrywer wil eer, kan dit op geen beter manier doen as om sy boeke te lees nie. En wie teenoor 'n teoloog dank wil betoon, kan dit die beste doen deur ernstig met sy teologie besig te wees. Dit dan is die rede waarom ons hierdie dag aan die teologie van professor Johan Heyns wy. Om hom net amptelik en formeel te bedank vir die buitengewoon groot bydrae wat hy oor 'n besondere vrugbare tydperk van veertig jaar tot die Gereformeerde teologie in Suid-Afrika gemaak het, sou nie genoegsaam wees nie. Hy verdien dank van sy vriende, kollegas en studente wat ook 'n teologiese gestalte aanneem.

Maar nou is dit so dat Heyns ons nie alleen voorgegaan het in die beoefening van die Gereformeerde teologie nie, hy het ' $n$ hele geslag Suid-Afrikaanse teoloë ook geleer dat wie vertroue het in die meriete van die Reformatoriese tradisie ook oop kan staan vir die waarheidselemente van ander tradisies. Juis daarom is ek oortuig daarvan dat Heyns begrip sal hê vir 'n waarheid wat die Duitse filosoof Friedrich Nietzsche ons geleer het. Nietzsche het naamlik gesê dat 'n mens jou leermeester sleg beloon as jy altyd maar net leerling bly en dit nooit tot selfstandige stellingnames bring nie 1 . Daarom het Heyns dit nooit van sy studente en kollegas verwag dat hulle hom moet napraat nie en stel hy'n eerlike en ernstige akademiese gesprek, waarin standpunt teenoor standpunt getoets word, hoog op prys. Dit is dan op hierdie wyse dat ons vandag ons opregte en diepgevoelde waardering teenoor hom wil betuig. 
Die eerste tema wat by hierdie simposium aan die orde kom, is die vraag hoedanig Heyns se siening van die teologie is. Dit is 'n tema wat die geleentheid bied om enkele basiese voorveronderstellinge en uitgangspunte wat in Heyns se teologiebeoefening 'n rol speel saam met hom in oënskou te neem. As sodanig kan dit ook vraagstukke aan die orde stel wat ter sake is vir die ander temas wat ook in die verloop van die dag bespreek sal word.

Nou stel die teologiebegrip as sodanig 'n baie uitgebreide onderwerp daar wat ' $n$ verskeidenheid van kwessies ter sprake bring. Ten einde die tema hanteerbaar te maak binne die daarvoor beskikbare ruimte wil ek dit toespits op die vraag na die wetenskaplikheid en konfessionaliteit van die teologie en met name op die vraag hoe beide elemente tegelykertyd geldig kan wees.

Wie die teologiebegrip van Heyns bestudeer, merk daaraan op wat in feite waar is van sy werk in die algemeen. En dit is dat sy standpunte oor die jare heen'n merkwaardige konstantheid vertoon. Wel stel 'n mens vas dat daar met verloop van tyd hier en daar 'n verskil in aksent optree, maar basies is daar 'n opvallende kontinuïteit van gedagtegang.

Die eerste keer waarop ek met Heyns se visie op die aard en wese van die teologie in aanraking gekom het, was in 1966 toe ek, kort nadat hy op Stellenbosch dosent geword het, die voorreg gehad het om sy kursus Inleiding tot die Gereformeerde Ensiklopedie mee te maak ${ }^{2}$. Sedertdien het hy met bestendige reëlmaat in talle grotere en kleinere publikasies sy visie in hierdie verband verder uiteengesit ${ }^{3}$. Ook nog weer in sy mees resente boek Inleiding tot die dogmatiek aan die hand van die Nederlandse Geloofsbelydenis kom dit aan die orde 4 .

Op sigself bly dit natuurlik 'n boeiende kwessie waarom daar aan die vraag na wat teologie is blykbaar geen einde kom nie. Self vermoed ek dat dit, onder andere die geval is omdat dit 'n tema is wat, alhoewel dit normaalweg in die prolegomena tot die dogmatiek behandel word, eintlik tuishoort in 'n postlegomena. En solank die laaste woord in die teologie nog nie gespreek is nie sal die finale woord oor die aard daarvan ook nog op hom laat wag.

DIE WETENSKAPSTEORETIESE VERTREKPUNT

Heyns se opvatting oor die wese en aard van die teologie lê heel duidelik binne die Gereformeerde tradisie. 'n Mens kan die wortels daarvan terug sien strek tot in die Nareformatoriese Ortodoksie 5 . So word een van die vernaamste onderskeidings van die Ortodoksie tewete dié tussen theologia archetypa en theologia ectypa by hom aangetref as hy sê dat die teologie tot taàk het nadenke oor die gedagtes wat God ons voorgedink het ${ }^{6}$. Sonder om in besonderhede daarop in te gaan, kan gesê word dat ook die invloed van Neo-Calvinistiese denkers soos Bavinck en veral ook Kuyper in sy werk aanwysbaar is ${ }^{7}$. Die gestalte van die Neo-Calvinisme wat egter 
die konkrete teelaarde was waarin Heyns se teologie aanvanklik ontwikkel het en wat 'n blywende invloed daarop sou uitoefen, was 'n Suid-Afrikaanse variant van die Wysbegeerte van die Wetsidee soos dit met name deur H G Stoker in die wysbegeerte van die Skeppingsidee uitgewerk is.

Opvallend in Heyns se hantering van die vraag na die wese en aard van die teologie is dat hy dit telkens plaas in die kader van 'n algemene wetenskapsleer en met name 'n wetenskapsleer wat sterk aansluit by dié wat deur Stoker ontwikkel is. Dit word al dadelik duidelik as gelet word op die wyse waarop Heyns wetenskap definieer tewete as gesistematiseerde en geverifieerde kennis van die werklikheid ${ }^{8}$.

Met die oog op die belang wat dit uiteindelik vir sy teologiebegrip sal hê, moet ons hier daarop let dat Heyns saam met Stoker sy wetenskapsbegrip uitwerk deur wetenskaplike kennis nadruklik van voorwetenskaplike kennis te onderskei9. Die voorwetenskaplike kennis, sê Heyns, is tevrede om die dat van die dinge te ken. Die wetenskaplike kennis daarteenoor wil deurdring tot die hoe en die wat daarvan ${ }^{10}$. Die voorwetenskaplike taalgebruik word as by die werklikheid betrokke, spontaan en dikwels meersinnig beskou teenoor die wetenskaplike taalgebruik wat afstandelikheid weerspieël en dus doelbewus logies onderskeidend en veelsinnig van aard is.

Ook in die beantwoording van die vraag welke gestaltes die wetenskaplike kennis aanneem en hoe die wetenskappe van mekaar onderskei word, sluit Heyns by Stoker aan wat hierdie indeling volgens die kenbaarheids-beginsel doen, met ander woorde in terme van dit wat geken kan word ${ }^{11}$. As eerste indelingsbeginsel in hierdie verband word dan hanteer die onderskeid tussen God en kosmos. Op grond hiervan word dan onderskei tussen die teologie waarin dit gaan om die geopenbaarde waarhede aangaande God enersyds en die kosmiese wetenskappe waarin aandag geskenk word aan die verskillende sfere van die werklikheid andersyds.

Die tweede belangrike indelingsbeginsel wat Heyns saam met Stoker hanteer, is die onderskeid tussen die kosmos as totaliteit aan die een kant en die kosmos as verskeidenheid van onderling samehangende werklikheidsfere aan die ander kant. Daarmee is die veld van die wysbegeerte as die wetenskap van die totaliteit van die kosmos enersyds en die terrein van die onderskeie vakwetenskappe wat elkeen gerig is op 'n besondere groep van samehorige gegewens binne die kosmos andersyds afgebaken. Die wysbegeerte is dus die wetenskap wat gerig is daarop om die grondstrukture van die geheel van die kosmos te verstaan terwyl die vakwetenskappe telkens 'n bepaalde werklikheidsfeer binne die kosmiese samehang van werklikheidsfere probeer ken.

Wat in hierdie stadium beklemtoon moet word, is dat in lyn met die Stokertradisie die kenbare kosmos die primêre kenbron van die wetenskap gemaak word ${ }^{12}$. Anders gesê: die wetenskap is kennis van die kosmiese werklikheid. Die vraag wat nou direk na vore kom, is wat die implikasie hiervan vir die teologie is. 
Van vroeg af is in die Gereformeerde tradisie immers gesê dat teologie kennis aangaande en spreke oor God is ${ }^{13}$ ? Herman Bavinck kon in aansluiting by die Nareformatoriese Ortodoksie met stelligheid beweer dat God die voorwerp van die teologiese wetenskap is. Maar hoe kan God die voorwerp van die teologie wees as die kenbare kosmos die primêre kenbron van die wetenskap is? As wetenskap kennis van die kosmiese werklikheid is, beteken dit of dat God nie die voorwerp van die teologie is nie of dit impliseer dat die teologie nie 'n wetenskap is nie. Om duidelikheid te kry oor hoe Heyns hierdie kwessie hanteer, moet die vraag dus gestel word wat na sy oordeel die objek van die teologie is.

\section{DIE OBJEK VAN DIE TEOLOGIE}

'n Beeld wat Heyns deurgaans in hierdie verband gebruik om sy posisie te verduidelik, is dat die teologie nie oor God beskik soos die plantkunde oor die plant as objek van sy ondersoek beskik nie ${ }^{14}$. Tog hou hy met klem daaraan vas dat die teologie 'n wetenskap is. Waar wetenskap kennis van die kosmiese werklikheid inhou, beteken dit dat die teologie God nie direk kan ken nie ${ }^{15}$. Die teologie ken God alleen langs die weg van 'n tusseninstansie, tewete sy selfopenbaring in die Skrif. In die openbaring is God nie direk en onverhuld aan die objektiverende denke van die wetenskap blootgestel nie. Wanneer God Homself openbaar, ontklee Hy Homself nie van 'n bedekking wat Hom vir die menslike rede ontoeganklik maak nie ${ }^{16}$. Inteendeel, Hy klee Hom aan sodat die mens Hom kan ken. Met name klee Hy Hom aan met dit wat aan die mens bekend is, tewete die kosmiese kreatuurlikheid. Hierdie aankleding vind plaas in die skepping, die inkarnasie en die inskripturasie. In hierdie gestaltes is God nie in sy pure Goddelikheid by die mens nie, maar altyd in die vorm van die geskape werklikheid.

Openbaring as tusseninstansie tussen God en mens kan dus beskryf word as die wyse waarop God vir die teologiese besinning ter beskikking is ${ }^{17}$. Die God van die openbaring kan nooit objek van die teologie word nie, want dan sou $\mathrm{Hy}$ ophou om God te wees. Die openbaring van God kan egter wel die objek van teologiese navorsing word. Langs hierdie weg word die wetenskaplikheid van die teologie gehandhaaf omdat dit iets kreatuurliks as objek het.

Alhoewel die mens God ook uit die algemene openbaring in die natuur en die geskiedenis kan ken, is die mens vanweë die werking van die sonde nie meer in staat om langs hierdie weg alleen suiwer kennis van God te kry nie ${ }^{18}$. Daarom is die mens vir kennis van God in laaste instansie op die Heilige Skrif aangewys. Die Bybel is openbaringsdokument en openbaringsinstrument ${ }^{19}$. Die teologie wat nie gebou is op en uitgaan van die Skrif nie is nie Christelike teologie nie.

In die proses waarin die Skrif bestudeer word, speel ook die belydenisskrifte van die kerk'n rol ${ }^{20}$. Hulle bevat die gesaghebbende kommentaar van die 
kerk op die Skrif. As sodanig dra hulle vir die teoloog gesag, maar dit is dan 'n afgeleide gesag. Veral in die dogmatologiese teologie word juis ook hierdie belydenisskrifte voorwerp van teologie - al is dit dan nie die laaste nie, maar die voorlaaste voorwerp 21 .

\section{$4 \quad$ DIE SUBJEK VAN DIE TEOLOGIE}

Teologie is dus alleen moontlik omdat God Homself in die Heilige Skrif openbaar het. As sodanig is die openbaring die objektiewe kenprinsipe van die teologie 22 . Maar die openbaring kan alleen geken word deur die geloof. Dit beteken vir Heyns dat die subjek van die wetenskaplike kennis van die openbaring die gelowige teoloog is. Geloof is dus nie alleen 'n voorwaarde vir iemand om 'n Christen te wees nie. Dit is tewens die conditio sine qua non vir die teologiese wetenskap ${ }^{23}$. In hierdie sin kan Heyns dan van die geloof as die subjektiewe kenprinsiepe van die teologie praat. Dit is belangrik om in gedagte te hou dat die geloof wel die voorwaarde vir die teologiese wetenskap is, maar nie die objek daarvan nie. Word die geloof as objek behandel, beteken dit dat die teologie godsdienswetenskap word 24 .

Nou is dit egter belangrik om daarop te let dat al is die geloof voorwaarde vir die teologie dit nie beteken dat geloof as sodanig teologie is nie 25 . Dit kan deur diegene wat daarvoor toegerus is tot teologie verwerk word. En dit weer hoef natuurlik nie noodwendig by alle gelowiges te gebeur nie 26 .

Om die verhouding tussen geloof en teologie verder op te helder, pas Heyns die onderskeiding tussen die voorwetenskaplike en wetenskaplike fases van kennis wat hy in sy algemene wetenskapsteorie gebruik daarop toe 27 . Dit hou dan vir hom in dat onderskei moet word tussen 'n voorwetenskaplike omgang met die Skrif wat as 'n naïewe praktiese geloofskennis bestaan enersyds en die teologie andersyds ${ }^{28}$. In hierdie praktiese geloofskennis gaan dit hoofsaaklik om die dat van die Bybelse waarhede, dit wil sê om die blote aanvaarding daarvan. In die wetenskaplik teologiese omgang met die Skrif daarenteen word deurgedring tot die hoe daarvan. Hier word, met ander woorde, gepoog om die openbaringswerklikheid na sy innerlike begryplikheid te verhelder ${ }^{29}$. Die voorwetenskaplike geloofskennis en die wetenskaplike teologie staan nie los van mekaar nie. Laasgenoemde is in feite slegs 'n voortsetting van eersgenoemde, maar dan op 'n wetenskaplike vlak, dit wil sê op 'n teoreties-sistematiese en krities-verifiërende wyse ${ }^{30}$.

Die voorwetenskaplike omgang met die Skrif, wat van die wetenskaplike teologie onderskei word, speel nie slegs op die vlak van die indiwiduele gelowige af nie, maar ook op intersubjektiewe en dit wil sê kerklike vlak ${ }^{31}$. Dit beteken vir Heyns dat die kerk as organisme 'n eiesoortige verantwoordelikheid met betrekking tot die uitleg en uitleef van die Skrifwaarhede het. Op die kansel en die kateder 
word weliswaar dieselfde waarhede verkondig, maar in 'n verskillende vorm. In eersgenoemde geval op voorwetenskaplike en met name kerklike wyse en in laasgenoemde geval op wetenskaplike wyse ${ }^{32}$. Die kerk kan en moet met die Skrif omgaan op kerklike wyse, maar nie op 'n wetenskaplike wyse nie. Die kerk as sodanig, sê Heyns, is nie toegerus of geroep om die wetenskap, ook nie die wetenskap van die teologie, te beoefen nie. Die funksie van die wetenskap word deur die universiteit vervul en daarom word ook die teologiese wetenskap deur die universiteit in sy teologiese fakulteit beoefen ${ }^{33}$.

Die kerklike omgaan met die Skrif is gerig op die prediking en die belydenis. Die wetenskaplike besigwees daarmee weer is gemik op die sistematisering en ordening daarvan en vind aan die universiteit plaas. Wanneer vanweë 'n noodsituasie 'n kerk nie toegang tot universitêre geriewe het nie mag hy wel sy eie kweekskool stig om predikante op te lei. So 'n kerklike teologiese kweekskool sal egter, volgens Heyns, nie as 'n wetenskaplike instituut beskou mag word waar wetenskaplik met die Skrif omgegaan word nie. Dit is 'n instelling waar, met die oog op die behoefte van die kerk kerklik met Gods Woord omgegaan word34.

\section{WETENSKAPLIKHEID EN KONFESSIONALITEIT IN DIE TEOLOGIE: ENKELE KONKLUDERENDE OPMERKINGE TER DISKUSSIE}

Wanneer 'n mens na hierdie kort herinnering aan enkele fasette van die teologiebegrip van Heyns saam met hom bestek opneem van die probleme wat daarmee opgelos is en welke probleme nog verder op ons gemeenskaplike teologiese agenda oorbly dan moet as winspunt aangeteken word dat hy die teologie op so 'n wyse benader dat een van die grondmotiewe van die Reformatoriese teologie, tewete die soewereiniteit en eer van God daarin sterk aan bod kom. In lyn hiermee moet Heyns se sterk aandrang gesien word dat God nooit met die wêreld of aan die dinge in die wêreld gelyk gestel mag word nie ${ }^{35}$. In 'n tyd waarin dit nie altyd meer die geval is nie slaag hy daarin om elke vorm van panteisme te vermy ${ }^{36}$. Tewens, hy kry dit reg om in 'n era waarin die teologie dreig om deur 'n allesoorweldigende pluralisme tot niksseggendheid gedoem te word duidelik en heldere onderskeidinge te maak ${ }^{37}$.

Aan die ander kant sal Heyns die eerste wees om aan te dui dat in sy denke daar spore is van 'n worsteling met probleme wat vir ons almal nog steeds 'n onafgehandelde opgawe vorm. So lees 'n mens in die boek $O p$ weg met die teologie dat die openbaring 'n tusseninstansie tussen God en mens is wat nader omskrywe kan word as God se wyse van tot beskikking wees vir teologiese besinning 38 . Maar in sy vroeëre artikel oor Die grense van die teologie staan met nadruk geskryf dat die openbaring nie 'n tusseninstansie tussen God en mens is nie, want in die openbaring ontmoet die mens God self ${ }^{39}$. Ek meen dat die skynbare diskrepansie tussen 
hierdie twee uitsprake nie as onnoukeurigheid opgevat moet word nie, maar as die aanduiding van 'n worsteling met 'n probleem waarvoor daar nie 'n gemaklike oplossing is nie. Juis van hierdie worsteling het Heyns in sy Dogmatiek waar hy die godsleer behandel, uitdrukking gegee met die stelling dat omdat God nie oor Homself geswyg het nie ook ons oor Hom moet praat, maar dat dit dan 'n spreke moet wees wat by Hom pas - 'n swygende spreke as't ware waarin die diepe eerbied vir die lewende God alle tekens van menslike hoogmoed sal uitwis ${ }^{40}$.

Wanneer dit nou gesê is, sou die vraag kon opkom of die probleem wat ons hier na vore sien tree nie tog in 'n mate saamhang met die wetenskapsteoretiese voorafbeslissings waarna hierbo verwys is nie. Moet ons in die teologie noodwendig begin met so 'n sterk klem op die diastase tussen God en mens? Soos reeds aangedui is dit ' $n$ uitgangspunt wat sekere belangrike probleme oplos. Maar is dit nie dalk 'n benadering wat ewe groot probleme skep nie? Dwing dit ons nie om met 'n subjek-objekskema te werk wat wetenskapsteoreties gesproke in die huidige tyd onder al groter druk te staan kom nie? Lei dit dan nie verder ook tot'n openbaringsbegrip waarin die openbaring gesien word bloot as 'n reeks waarhede nie? En dit is 'n posisie waarteen Heyns tog self beswaar aanteken ${ }^{41}$.

Sou dit nie loon om naas die streng diastase-model tog ook oorweging te skenk aan 'n iets meer relasionele benadering van christologiese en pneumatologiese signatuur nie? Ek vermoed dat daar in Heyns se werk self wel hier en daar'n suggestie is wat in hierdie rigting wys. Dit wat hierbo in verband met die skynbare diskrepansie gesê is, sou 'n voorbeeld hiervan kon wees.

Miskien sou so 'n iets meer relasionele aksentuering ook die weg kon open vir die hantering van enkele vrae wat saamhang met die toepassing van die onderskeid tussen die voorwetenskaplike en wetenskaplike fases van kennis op die teologie. Wanneer hierdie wetenskapsteoretiese onderskeid bepalend word vir die verhouding tussen die kerklike en wetenskaplike omgang met die Skrif lei dit tot posisies wat verdere besinning vereis. Is die onderskeid tussen belydenis en teologie werklik so strak as wat die toepassing van die vermelde wetenskapsteoretiese onderskeiding impliseer? Dit is inderdaad so dat belydenis nie teologie is nie. Dit wil egter nie sê dat daar nie in 'n belydenis 'n teologiese dimensie kan sit nie of dat die teologie nie 'n rol gespeel het in die totstandkoming van kerklike belydenisse nie. Die teologie is nie net die wetenskaplike verwerking van 'n belydenis nie, maar kan op sy beurt ook weer gerig wees op die totstandkoming van 'n belydenis. Is die grens tussen die kerklike geloofsdenke en die wetenskaplike teologie nie in feite vloeibaarder as wat die toepassing van die onderskeid voorwetenskaplik-wetenskaplik daarop impliseer nie?

En kan dieselfde vraag nie ook gestel word wanneer dit gaan om die kwessie van die institusionalisering van die teologiebeoefening nie? Is daar werklik so 'n drastiese verskil tussen die denke wat aan 'n teologiese kweekskool enersyds 
en aan die teologiese fakulteit van 'n universiteit andersyds geskied? Is denke pas teologies as ' $n$ bepaalde wetenskapsteorie dit as sodanig verklaar? Moet 'n mens nie liewer andersom redeneer nie? Die teologie moet self bepaal wat hy is en dan kan aposteriories vasgestel word of dit 'n wetenskap is of nie. Ek is oortuig daarvan dat die wetenskaplikheid daarvan wel bevestig sal kan word. Maar die wetenskaplikheid van die teologie kan nie op grond van 'n aprioristiese wetenskapsbegrip bewys word nie 42 . Heyns het immers self in een van sy artikels geskryf dat die grense van die teologie primêr van binne uit, dit wil sê vanuit die wese van die teologie, gestel word ${ }^{43}$.

Wanneer die strakke onderskeid tussen teologie en belydenis waarvan so ewe sprake was vloeibaarder word sodat die kerklike belydenis nie net tot 'n voorteologiese fase beperk word nie sou dit moontlik word om die wetenskapsteoretiese potensiaal daarvan te ontsluit. Dit sou beteken dat die belydenis nie net wat sy inhoud betref nie, maar ook na sy vorm vir die teologie van fundamentele betekenis sou wees 44 . In plaas daarvan dat die wetenskaplikheid van die teologie deur die konfessionaliteit daarvan in die gedrang gebring word, sou ek wou waag om te sê dat dit daardeur begrond word. Daarmee is 'n fundamentaalteologiese stelling gemaak waarvoor ek vermoed dat my vriend Johan my vir 'n samespreking sal wil oproep, maar dit was dan ook met opset. Want om DV nog 'n hele klompie jare ernstig oor so 'n soort vraag deur te praat - dit is waarvoor 'n emeritaat bedoel is.

\section{NOTAS:}

1 Vergelyk G Puchinger, Theologische persoonlijkheden, Kampen 1973, 14.

2 Die kursus was aangebied aan die hand van 'n diktaat wat in 1966 deur die NG Kerk-boekhandel afgerol en uitgegee is.

$3 \quad$ Kyk byvoorbeeld "Teologie en natuurwetenskap", NGTT 7(1966), 34-45; "Reduksie in die teologiese wetenskap", $B C W 3 / 8,4-8$; "Die grense van die teologie", Die waardes van die Afrikaner (1968 Jaarvergadering: SA Akademie vir Wetenskap en Kuns), Kaapstad 1969, 73-87; Op weg met die teologie, Pretoria 1974 en Teologiese Etiek, Deel 2/1, Pretoria 1986, 290-302.

$4 \quad$ Halfway House 1992, 24-37.

5 Oor die teologiebegrip van die Nareformatoriese Ortodoksie kyk, onder andere, G E Meuleman "De theologie als habitus en als doctrina volgens enkele vertegenwoordigers der oudprotestantse orthodoxie", GTT 84(1984), 221-247.

6 Vergelyk W D Jonker, "Wat is teologie? Die standpunte van Bavinck en Kuyper", in: Woord en wetenskap (Gedenkbundel aan Prof F J M Potgieter onder redaksie van D F M Strauss, H J S Stone, J C Lombard en J M Gerber), Bloemfontein 1977, 32-47. 
Vergelyk Jonker, a a, 1977.

8 Kyk J A Heyns en W D Jonker, Op weg met die teologie, 29 en H G Stoker, Beginsels en metodes in die wetenskap, Potchefstroom 1961, 134-138.

$9 \quad$ Kyk die artikel "Die grense van die teologie", 80 en $O p$ weg met die teologie, 20-22. Vergelyk ook W W Pretorius, Kosmologiese aspekte in die denke van J A Heyns met besondere verwysing na sy wetenskapsleer en sy beskouing van die teologie as wetenskap. Ongepubliseerde MA-verhandeling, Universiteit van die Oranje-Vrystaat, 1975, 2.

10 Kyk Op wegr met die teologie, 20. Vergelyk Pretorius, $a w, 3$.

11 Vergelyk Op weg met die teologie, 55-58 en Pretorius, $a w, 8$.

12 Op weg met die teologie, 30 en 150 . Vergelyk Pretorius, $a w, 8$.

13 Kyk W D Jonker, Wat is teologie, 32. Vergelyk ook Op weg met die Teologie, 150.

14 Kyk byvoorbeeld $O p$ weg met die teologie, 153.

15 Kyk $O p$ weg met die teologie, 150 en Die grense van die teologie, 74-76.

16 Op weg met die teologie, 151.

$17 O p$ weg met die teologie, 152. Vergelyk egter ook Die grense van die teologie, 75 .

18 Kyk J A Heyns, Dogmatick, Pretoria 1978, 52.

19 Die grense van die teologie, 75.

20 Vergelyk Die grense van dic teologie 76, asook Inleiding tot die dogmatiek, 26.

21 Kyk W D Jonker in sy bydrae tot $O p$ weg met die teologie, 293.

22 Vergelyk Die grense van die teologie, 77 asook Op weg met die teologie, 153.

23 Die grense van die teologie, 77. Vergelyk ook $O p$ weg met die teologie, 182 waar 'n uitsondering vermeld word op dit wat hier gesê is. Oor hierdie hele problematiek, kyk ook H M Vroom, "Vooronderstelt theologie geloof", in: $\mathrm{H}$ M Kuitert, J Veenhof, H M Vroom (reds), Cultuur als parther van de theologie (Opstellen over de relatie tussen cultuur, theologie en godsdienstwijsbegeerte, aangeboden aan Prof dr G E Meuleman) Kampen 1990, 125-139.

24 Die grense van die teologie, 77; Op weg met die teologie, 184.

25 Op weg met die teologie, 183-184.

26 Vergelyk $O p$ weg met die teologie, 184. 
27 Kyk Op weg met die teologie, 128 en 190.

28 Op weg met die teologie, 128.

29 Op weg met die teologie, 129.

$30 \quad$ Kyk Op weg met die teologie, 131.

31 Kyk Op weg met die teologie, 191.

32 Kyk Op weg met die teologie, 190.

33 Vergelyk $O p$ weg met die teologie, 191. Hiermee wys Heyns dus die standpunt van Karl Barth en Emil Brunner af wat die kerk as die subjek van die teologie sien.

34 Op weg met die teologie, 192.

35 Vergelyk Inleiding tot die dogmatiek, 6.

36 Vergelyk C J Wethmar, "Teologie en samelewing", in: H M Kuitert, J Veenhof en H M Vroom (reds), Cultuur als partner van de theologie (Opstellen over de relatie tussen cultuur, theologie en godsdienstwijsbegeerte, aangeboden aan Prof dr G E Meuleman), Kampen 1990, 37.

37 Vergelyk D F Theron, Die Koninkryk van God in die teologie van J A Heyns, Ongepubliseerde proefskrif, Universiteit van Suid-Afrika, 69.

$38 \quad$ Kyk bladsy 152.

$39 \quad$ Kyk bladsy 75.

$40 \quad$ Kyk bladsy 37.

41 Vergelyk Die grense van die teologie, 84, voetnoot 5.

42 Vergelyk G E Meuleman, "Theologie aan de universiteit", GTT 1(1991), 22 en 25 .

43 Die grense van die teologie, 73.

$44 \quad$ Vergelyk E Jüngel, "Theologie in der Spannung zwischen Wissenschaft und Bekenntnis", in: Idem, Entsprechungen: Gott-Wahrheit-Mensch. Theologische Erörterungen, München 1980, 37-51. 